\title{
Screendance Festivals and Online Audiences
}

Moderator: Harmony Bench, The Ohio State University

Gabri Christa, Barnard College; Director, Moving Body - Moving Image

Yolanda M. Guadarrama, Director, Movimiento en Movimiento

Cara Hagan, Appalachian State University and Director, ADF's Movies by Movers

Kelly Hargraves, Director, Dance Camera West

Marisa Hayes, Co-Director, Festival International de Vidéo Danse de Bourgogne

This roundtable was presented on 13 March 2021 as part of the symposium connected to this special issue, This Is Where We Dance Now: Covid-19 and the New and Next in Dance Onscreen. It has been edited for clarity and length. The video of the full roundtable conversation and $\mathrm{Q}+\mathrm{A}$ is viewable at: https://doi.org/10.18061/ijsd.v12i0.8372

ROUNDTABLE

SCREENDANCE FESTIVALS AND ONLINE AUDIENCES

With Gabri Christa, Yolanda M.

Guadarrama, Cara Hagan, Kelly

Hargraves, and Marisa Hayes

Moderated by Harmony Bench

Saturday, March 20

9am LA / 12pm NYC /

$4 \mathrm{pm}$ London /

3am (21/3) Sydney

THIS IS WHERE WE DANCE NOW COVID-19 AND THE NEW AND NEXT IN DANCE ONSCREEN IP THE OHIO STAT́́ UNIVERSITY
GLOBAL ARTS + HUMANITIES DISCOVERY THEME

Photo by Elena Benthaus, used with permission. Design by Regina Harlig. 
Keywords: screendance festivals, online film festivals, dance film, audiences, equity, international, curation, drive-in theater, access, representation, community, local, global, glocal, Moving Body - Moving Image, Movimiento en Movimiento, R.E.D. International Film Festival, REDIV Iberoamericana de Videodanza, ADF's Movies by Movers, Dance Camera West, Festival International de Vidéo Danse de Bourgogne

Harmony Bench: I'm excited for this roundtable: Screendance Festivals and Online Audiences. I've asked each of our presenters to take 3-5 minutes to address how they adapted their festival format in 2020 or 2021, including successes and lessons learned for the future, and what practices they might take forward. After they have an opportunity to speak, I will follow up with some questions just to get the ball rolling, and then we'll open the floor for a general Q\&A.

Gabri Christa: $\mathrm{Hi}$, everyone. I'm really excited to be here with these other wonderful presenters. My name is Gabri Christa. I'm Associate Professor of Professional Practice at Barnard College. I'm a dance and filmmaker and also the founding director of the biennial Moving Body-Moving Image festival, which I started in 2016 when I came to Barnard. It's a small one-day festival focused on community creation-not too many films, highly curated. The audience has time to sit, watch all the films together, watch the installations, the virtual reality, see the second program, have time to eat, drink, have wine, and then go to the discussion.

It came out of a long idea of wanting a festival around themes of social justice and social issues, and looking at representation so that it wouldn't be an all-white, young space. As a maker and viewer, I want to have guidance when I'm watching films. I started the festival with the theme of the Moving Brown Body onscreen, which now would have been the BIPOC body, with films from Africa, Asia, Europe, and all of the Americas. To foreground equity, the composition of the jury reflects the theme, as well as the choreographer, director, producer of the films selected. In other words, the jury and the films both reflect the theme. For example, we wouldn't accept a film around Brown bodies if it upheld a white gaze. This became more difficult with our 2020 festival, focused on the Moving Aging Body, but we did have an intergenerational panel of jurists aged 24-80.

April $4^{\text {th }}, 2020$, we were supposed to have the live version of the Moving Body-Moving Image festival. March $15^{\text {th }}$, we heard that we were going on lockdown. I decided right away I could not bring an aging population in. I had no idea how we were going to do it, because at the time there were no festivals online yet. I asked my team: who is our audience, what do we want their experience to be, and what limitations might they encounter? I came away with two key ingredients that determined all decisions that were made: accessibility and equity. The festival had to be easy to navigate and open and free to all. The festival had to remain a community event. So with that in mind, we 
decided that everything had to be on one website, that we didn't want to do YouTube or Facebook or reservations, and that people could just come to the website and click and watch. I was lucky to have funding from Alzheimer's Society, UK, and the Global Brain Health Foundation, and the support of the Barnard Dance Department and The Movement Lab, which I also direct.

Both programs were short, 45 minutes. The curation was quite intense because of the time limit we set. Some of the films that didn't get in became part of the installation, and we had still virtual reality, and a speaker series. Part of the difficulty was not just doing a festival around aging, but also not having only aging white bodies on screen. So the process was intense to really create and keep the diversity.

We kept the festival up for 48 hours instead of one day, and we had an astonishing turnout representing 61 countries. Normally in the festival, we got 200-400 people. We had 11,231 festival visitors, meaning people that watched 1-2 things, and we had 5,265 film viewers who watched everything. What it suggests is that there is a far larger audience than I was thinking there would be. Also, I don't think it hurt that we were, I dare say, one of the very first festivals that went online. We got everythingthe whole festival, the whole website, up in two weeks. I'm incredibly proud of the three of us for doing that.

Yolanda M. Guadarrama: Hi, I'm Yolanda. I will introduce the festival I direct, Movimiento en Movimiento, and I will also mention both R.E.D. (Residency Eina Danz) International Film Festival (RIFF), a Norwegian festival where I do the curation, and REDIV Iberoamericana de Videodanza, the Iberoamerican Screendance Network.

movimientoenmovimiento.wordpress.com is the link for the international screendance festival that I direct. There are three curators. Normally the festival is celebrated annually during October or November. And then we show whatever thing with movement, experimental and traditional screendance with strong meanings, literature, social and philosophical issues, body identity. So we have a wide spectrum. Normally the festival consists of 20-30 films in the official selection, and about two video-call-screendance live performances. There are face-to-face screenings with talks with the creators and pre-recorded 2-minute video interviews to show with films. We exhibit the films in a loop format for about 20 days at Centro de Cultura Digital in Mexico. We have an award for best selected pieces. We have workshops and Mov en Mov Magazine with texts about screendance and the festival printed in paper and online. And for the past 9 years, we have also ended with an online permanent gallery published a couple of months after the screenings. The $9^{\text {th }}$ edition dedicated to body identity was online during 2020 . We had 26 films in the official selection, which were shown together with a pre-recorded 2-minute video interview, a call-screendance live performances, no face-to-face screening. The exhibition of the pieces in loop format at Centro de Cultura Digital for 20 days still happened, but online, because they have a platform. The problem was how to do it free online. The selection was divided into 6 
thematic programs, and 3 days dedicated to each program. We stated the importance of the pieces and the program with the activities dedicated to them. For example, the Day 1 program was a talk about the films with experts. Day 2 was a written chat with the creators. And Day 3 was a loop of the program for 8 hours, so people could sit there and watch the films all together with the interviews. There was also an award for the best selected pieces and the workshops, which had to be online. We also have Mov en Mov Magazine with texts about screendance or the festival. They were printed on paper and they were released online. As an extra, there was an online interview about body identity, comparing the body online and the body face-to-face, of course, in performances also. And then 60 international screendance creators, curators, philosophers, writers, etc. were briefly interviewed. It was very enriching for everybody, I think. That's what happened with Movimiento en Movimiento in Mexico.

RIFF: R.E.D. International Film Festival is a Norwegian festival in Einawood directed by Ella Fiskum, and I am the co-curator. This festival is normally in July and consists of about 30 films. Some films exhibited in the same galleries of the venue, R.E.D., to be visited during one week, some screenings are in R.E.D. Arena, and some more traditional films are screened in R.E.D. Drive-in. We normally have face-to-face concerts and live dance performances, awards, workshops and international SØNDANZ FLAC, that is a film lab and art camp. RIFF 2020 was hybrid, online and face-to-face, no exhibition in the gallery. 23 films were selected. There were some face-to-face screenings and live performances in R.E.D. Arena and Drive-in with 30\% occupancy. The online version was a publication and sale of the online RIFF Magazine 2020, which provided access to all the films for one month. There were also awards and some local workshops. The result was a good balance of face-to-face and online public.

Finally, RED Iberoamericana de Videodanza, REDIV, which is the Iberoamerican Screendancee Network, started in 2016. This is a network of managers, researchers, artists, and screendance festivals, which work transversally through various projects and actions of curatorship, dissemination, training, management, etc., everything around screendance. We are 23 international festivals at the moment, 3 academic projects, and 10 independent collaborators. About 10 festivals celebrated an online edition during the Covid lockdown. We were really very active!

Cara Hagan: Hi, my name is Cara Hagan. I'm the director and curator for ADF's Movies by Movers, an annual international screendance festival under the auspices of the American Dance Festival. As such, we're kind of a festival within a festival. Our audience and our community includes those who are attending ADF, local folks in North Carolina who are traveling from towns and cities around Durham to come to $A D F$, and because we do the majority of our screenings at the Nasher Museum of Art on the campus of Duke University, we do get spill over from their events for folks that come to our stuff. So essentially, ADF's Movies by Movers is part of a really dynamic tapestry of things happening all summer at Duke University through the American Dance Festival. All of the screenings are free. Before the lockdown, I would say that our 
structure was pretty traditional: most of the events happened in a screening room where people would come to sit. We would have artist talks, do some workshops in the studios, and some satellite screenings in specific spaces around Durham during the summer. A lot of the events would be spread out throughout the summer. When lockdown happened, we didn't really have a choice of whether or not we would pivot online. We were kind of in response mode. How do we create a platform to put the films on, and how will people have access to them, and how will we do the artist talkbacks?

One nice thing is that we had more films than we've had ever in the festival this past year. We showed about 80 films, which was twice the amount that we show generally because we have limited time in our screening spaces. And we had all Zoom artist talkbacks. The feedback we got was that folks really appreciated being able to have a truly international experience, where folks who would not have been able to make it to our festival came and talked about their work. This year we're going to be online again, and we've had more time to think about how we'd like to do that. We're crafting something more intentional, more focused, and in my opinion, more intimate feeling. By the time we got to the summer last year, people were already feeling inundated with all of the offerings. And I know this community, we all try to be at everything. So trying to create some more space and a more personal experience became really important to me after the first online iteration of the festival. And trying to create something where the artists also feel that their work isn't being lost in a sea of the internet.

During this Covid time, now that we're a year into it, I wonder if 'international film festival' now means international access in a post-Covid world. We've always labeled ourselves an international screendance festival because we accept submissions from all over the world, but to truly be able to have that international conversation space became really important. So that's a question that I have. What new considerations we will have for caring for the work once we're live again with regard to things like accessibility and exclusivity? How much access do you give people? Do you put up a paywall? We did not, and we're not going to this year. For how long do you put films up? Do you limit the time that they're up? And if so, what is the sweet spot for how much time you leave things up? And what amount of time honors the artist's wishes, but also gives the audience a chance to really engage with the work? Finding that balance has become really important. And my last question is how are we going to reimagine the festival experience for a hybrid post-Covid world? Because I have this feeling it's going to be a staggered process for us to get to the point where the pandemic is really totally over. Even if we have events in-person, there will be places where there are outbreaks and places go on lockdown, so that issue of access and what a festival looks like is going to be a big thing moving forward. So, there are things that we still have to reckon with because of the pandemic that I think we're going to be experimenting with for quite a while. 
Kelly Hargraves: Hello, everybody, my name is Kelly Hargraves. I'm in Los Angeles. I founded Dance Camera West 21 years ago, and I've now returned to it as of two years ago. My day job is in film distribution with independent film companies, so I have a lot of experience working with theaters and with streaming companies. We actually went through a pivot when I came back to the festival because my previous director had made it a much more expansive festival with live events, live performance, and all over the city, and I wanted to come back to a more traditional film festival view. So when I came back, we were already envisioning a hybrid version of a festival. We came back to a traditional four-day event in one venue, we showed 75 or 80 films, because I had always wanted to expand the vision of what could be shown so I jammed in 9 programs in one day. It was like a marathon. We had invited guests and speakers. Our festival is in January, which is very notable, because we got it in before the shutdown, and we had already planned a March online version. We went up March 1st on OVID.tv, our streaming partner, with a 30-day version of the festival where people would pay $\$ 10$ and have seven-day access. And we had started that because as soon as the festival was over people would say "I missed it. I'm sorry, I didn't come. Where can I see your films?" So because I work with streamers now, I did that. One of my goals when I started again, was to pay artists. It's a really important part of my expansion plan for this festival. We went with online streaming so that they would get paid, and we work out distribution deals with broadcasters.

When it came to the idea starting 2021, I didn't want to do an online festival because we were already doing that. And I was steadfast about that. Instead, we created a finishing fund for BIPOC artists. We decided to pair Los Angeles based BIPOC artists with mentors to take their films and kind of bump them up into that next level. We have two artists now working on their films.

So, fast forward, all of a sudden I started getting phone calls from performing arts centers who didn't have programming. They were asking, "Can you send us films? Can you send us films?" So we quickly started a touring program with UC San Diego and with the Hopkins Center, and again, the artists made money, we split it 50/50. When it came to the 2021 festival, a couple of Los Angeles venues, like The Broad Stage and Théâtre Raymond Kabbaz called and said, "We want to do this. How can we do it?" And that's when the idea of building a drive-in started. There's a documentary that shows how we built the drive-in, and also all the films that we screened, or interviews with the artists, which is something new. Building a drive-in is not a cheap initiative, and I knew we would lose money, but thought, "If there's ever a year to lose money, this would be it."

Now we are teaching a lot. We're doing a lot of workshops with university students and community dancers. As they pivot to having to make dance films, you have to have that documentation versus screendance "aha moment" with them. I keep laughing, "Now you have to listen to me. You haven't wanted to for 30 years, but now is the time." 
The 2021 festival will be on OVID.tv for one month with a fee, and then we're becoming a total streaming channel. We will stay on over throughout the year. Right now, it is only Dance Camera West films, but it doesn't have to be. I am a dance film distributor at this point and willing to talk to all of you about films that should be up there. We will start with this year's films and last year's films, but I may go back through our archives and put all the greatest hits up as well. As to 2022, I'm not even thinking about it.

Marisa Hayes: Hi everyone, my name is Marisa Hayes. I'm the co-founding, co-director of the International Video Dance Festival of Burgundy in France. We are currently preparing our $13^{\text {th }}$ edition. I co-direct the festival with Franck Boulègue. And I'm also a guest curator for the National Choreographic Development Center near Paris. And I also co-curate the International Screendance Festival Freiburg. One of the underlying elements of our festival is a collaboration with other institutions, both in France and abroad. To provide a bit of context about our festival, so you understand what's important to us during the so-called normal times, we have three major axes of our work, which is of course festival screenings. We do have an open call that we curate, but we are also very interested in thematic work. And one of the signature elements of our festival has been the commissioning of thematic collective films, or omnibus films. So for such a project, we have one common theme that could be a visual motif, a piece of music, or a political prompt, and we ask artists from around the world via open participation to create one segment, which is then edited together to complete one final film. The objective behind this is to provide as many diverse perspectives and representations exploring one theme from as many angles as possible, to allow for a rich exchange of ideas coming from different cultures. Alongside screenings, another very important aspect of our work at the festival is to provide as many workshops as possible. And those range from a one-week intensive for emerging professional artists who might like to create their first work of screendance, to school children and families in the local community. So there's a wide range of kind of outreach and educational activities that we provide during the festival, and also throughout the rest of the year. Another aspect of the festival is to increase funding for screendance. For our third year in a row, this year in collaboration with other choreographic centers in France and Germany, we've been able to offer a two-week screendance production residency at a national choreographic center in France. The responsibility for the residency is shared by a network of partners, and it's normally accompanied by an $€ 8,000$ production grant.

Harmony had asked us, what is our approach to curating? And I'm always really inspired by the Latin root of curate, curare, which is to care for. There's a lot of really interesting philosophical material circulating about the idea of care, thinking about the care of the work, the care of the artists, the care of our public. One of the things that has been a really disastrous result of this pandemic year has been the economic precarity of artists, many of whom are not working or don't have stable employment. 
We were able to negotiate with different cultural performing arts organizations in France and Europe, many of whom have funds for live work that's not currently being used, and we were able to expand our residency program for the current call that has just been launched this year. This year we're going to offer two residencies instead of one, that will include a two-week residency period, but we've also been able to nearly double the financial grant, which has gone from $€ 8,000$ to $€ 15,000$. I'm very grateful to our partners who are willing to shift some of the funding for live work, recognizing that right now, it is possible to continue making screendance, and that it's very essential to support artists at the present time.

Another extension of this idea of care is thinking about format. The exhibition format is always important, but as most screenings are now taking place online, I think it's more important than ever to check in with artists to make sure not to assume that work is suitable for an online internet screening. Has the work been made in installation format for a gallery exhibition? Has the work been made envisioned for a big screen? And of course the question of sound. A lot of our artists have asked us, "Can you please tell the audience to wear headphones while they're watching the work for a better experience?" We need to pay attention to the technology and format, because it has been frustrating for artists who prefer to share their work on a large screen or who have very particular concerns regarding sound.

I completely echo the sentiment of how we can touch a much wider geographic audience and have really rich discussions that might not otherwise have taken place. In our approach to the festival, we are very interested in the idea of glocal, the global and the local, and how we join the two together in dialogue. The international aspect has been somewhat simple because even pre-pandemic, we were used to communicating via Skype and Zoom. But with the closing of physical theaters and institutions here, it has been difficult to maintain that connection to the local community. The connection has been severed a bit during the pandemic. Whereas the international connection has really increased tenfold with all of the opportunities we have to dialogue online. And what's unfortunate about that is that often when you dialogue with the local community, you're touching people who might not otherwise be a part of the arts community, people who might not otherwise attend a screening. I really hope that as we reimagine the future, we can regenerate, recreate, and renew our ties with both the local and the international community.

Harmony: Thanks to all of you, what wonderful ideas and perspectives. I want to recognize the labor and investments that each of you had in sustaining your various festivals in these past several months, and to thank you for the work that you have done. One of the things that I appreciated across the presentations was a sense of each of the festivals' values and what each of you are trying to do as curators. I'm curious to learn a little bit more about the audiences that you have really been tending to and caring for, and are they the same as you look ahead to 2021, 2022? 
Cara: When we have had live screenings, I often felt like our audiences were too homogenous. Those of you who know my work know that I'm very concerned with representation, both onscreen and offscreen, and I found myself struggling with how to diversify our audiences more effectively in terms of racial diversity, as well as age and background. In pivoting online, we got some new folks. In some of the talkbacks, there were folks who had never been to our festival before. And I got emails from people who had never been to the festival before, saying, "Hey, I saw this thing, thanks for putting it up. I would have never come to it otherwise." So knowing that there are other people out there who would be interested to see the material that we're curating for audiences means that we can really think about the next time around how we're marketing it, and who we're marketing it to, and not relying so much on the ways that we have done it before, where you're reaching the same people who already come to ADF. What kind of outreach do we need to be doing to make sure that local audiences that we haven't seen in our theater feel welcome? Also being able to tap into the university community a little bit more, because a lot of people have been looking for material, workshops, and access to resources. And we have those. So that's another way of bringing community in.

Kelly: With the drive-in, people just came because it was a great fun event. So we created new viewers that way. One of the things I've done is I've created a screening committee of about 25-40 dance performance artists in Los Angeles, because I want our vision to be very Los Angeles, what it looks like and its beautiful diversity, and that has helped diversify our audience a little bit. But we'd never have film people in our audience, and I think that will start with OVID.tv, which is an experimental film channel.

Gabri: I think what happened for me, well, it's a totally new festival and also smaller, but I do find that representation and theme is what really sets the audience. So when we did the Brown body theme, that was our audience. When we did it around aging, that was the audience. I find that the people came mostly for the theme and not so much for the screendance, because a lot of the audience is not normal screendance folks. The next festival will be on disability. And then the part that's important is how do you hold on to the diversity?

\section{Audience Q+A}

Mitchell Rose: With the hybrid model becoming a more permanent thing, now that people have found that it works, it seems with the inevitable fall-off rate, that a lot more people are going to see the first few films than the last few films. Has anyone found any creative solutions to that?

Kelly: I can say when I did it live, one of the comments I got from the audience was it was so eclectic, so there was no way they were going to miss a thing because they didn't know if a blockbuster might be between two DIY films I love. So that's how we 
program. That's one of the reasons I don't use themes, because I want people to not know when to be there or not. You just have to come. It's all in.

Gabri: Using themes, even themes like abstract films, or experimental films, or documentaries, help the people that come to the audience who don't know this field. My experience has been that people just come open anyway, like, "Okay. Let's go to see this thing that we don't know about." And then hopefully we also create a larger audience for this art form.

Yolanda: I also divide by themes, and people do come accidentally, but a lot of film lovers and dance lovers come too from around the world. But for each program, there are many ways to watch the films. For one example, people could go around and click the five films of the programs whenever they wanted in any order, and then it was followed by discussion so they were interested in watching. Another day they could watch them as if they were in a screening, but it was one hour program and it was an eight-hour loop, so they could arrive whenever and watch whatever film. There was also discussion with creators, and having the possibility to click on that film so they read some comments. People really watched many films, and we gave them many perspectives to see them.

Cara: We had shorter screenings. Some of them were only 15 minutes long. I was definitely thinking about audience patience when I put the screenings together-how long are people actually going to sit to watch this and what films are not going to get seen if we make this too long? Some things were just one film and a discussion with the filmmaker.

Marisa: We recently dared to be short, which is interesting because normally with some cinemas that we collaborate with, they'll tell us, the minimum, you have to have at least one hour of programming. So we're quite used to that mindset. But just last week we showed three films, and even with an introduction and translation in two languages, the program didn't go beyond 35 minutes. For us, that was quite short and unusual, but the viewing numbers showed that it works really well.

Kelly: For the drive-in, we did two screenings each night, and each program was an hour, so that we could get cars in and out between screenings. And honestly, it could've been longer.

Harmony: So what then is the future of the long film? If the tendency is to go in the direction of these shorter experiences, does that mean the death of the long-form film, or will there be a resurgence post-pandemic?

Gabri: We get the short films, and then find space for the longer films. I think that it's going to be a hybrid personally. I love the longer format, but I do find that it's harder for an online festival. Maybe the shorts will go online and the longer films will be in person. As a maker, I found that my longer films have been in museums, and that was 
incredibly gratifying because it brings a different view to it. People have more patience to just sit and just watch things on a loop.

Yolanda: I think there's audience for everything nowadays but we are getting tired of just being on the internet. For example, at RIFF Festival, we accept long feature films and documentaries, and they are in the magazine and people can sit and watch them whenever they want. They can carve the time when they want. Long feature films are going to come back. So there's a space for everything, but if you have an online program, you need to have it short, or only one film.

Marisa: I think this is a really important topic. And I appreciate what Yolanda said about there being an audience for everything. The screendance community is so diverse, but there hasn't been a very good place for longer films. And there are very practical reasons for this. Many times curators' hands are tied because of the spaces that they're working in and the length of time they have for a screening. But it is really important to find the place, space, and time for longer films, so that artists don't feel forced to make a certain format simply because they won't be able to share their film if it goes beyond a certain length. I think something really important about this is the relationship that you have to the work. When people in Western society go to the cinema, or a screendance festival, or the theater, they feel very stiff, they stay in their place, they don't even get up to go to the toilet, and feel they must adhere to a certain behavior. That doesn't exist in many other cultures that have longer durational artistic events, where people might feel free to take a nap, grab something to eat, leave the room and come back. We really encouraged people to do that during our durational screening.

Coming back to what Yolanda said, I think one of the places that you could find for longer films online would be the setup where you have a film that's up for 24 hours and people can have the time to watch it at their leisure and really create their own temporal relationship to the film. So perhaps the best format is not live-streaming on Zoom, but to have a home for the work online where people can come to it and create the relationship and the space that they want for it.

Harmony: Anabella Lenzu has a practical and important question in the chat which has to do with music rights and how you all have navigated rights, restrictions, copyright around music, navigating take down notices from YouTube and the like. How has that worked for you or how have you worked around the very real concern of music rights when you're streaming online content?

Cara: I really try to stress with the artists, if you don't have rights to the music, I might not be able to show it. I have this conversation with students all the time because their projects get taken down all the time. I think people are getting more hip to it like, "Oh, okay. Either I have to go to BMI and pay for this, or I've got to find something that's not copyrighted, or I have to get something made that is original." That leads to some nice 
topics of conversation about the aural experience of films, including soundscapes and ambient sound.

Kelly: Yeah, I'm echoing that while I'm doing these workshops, and speaking to them about how that changes the structure of their film, when they're trying to create a chorus-verse four-minute film where maybe they have two minutes of a film. One of the ideas for next year is to focus more on music, maybe by doing some screenings that have live accompaniment by musicians, just to kind of get dance filmmakers and musicians connected.

Harmony: Jeanette Ginslov asks, "Do you think the online in real life festival format needs to change, i.e. running films in a linear format? Could one not use a collection or an archive (with trailers), so the online viewer selects what they want to see? Put the control in the audience's hand as online experience is such a temporal and ephemeral experience? And then leave the archive up for a while." Might that be a good model?

Kelly: That's our post-festival model. There's a photo for each film and you can click on them as you go. I do find having to sit for a duration of 90 minutes online is challenging for me even, especially because I found it hard to kind of not have program notes at the same time. I don't know. I'm sad to say this, but I'm really challenged by watching online festivals. I get frustrated.

Marisa: We keep an archive on a page called Numeridanse, which is a bilingual video archive site where you can make your own playlist. You could go through the hundreds of videos and play with being your own curator in that sense.

Yolanda: You can be an active festival and the can audience choose whatever, or you can choose a traditional way. You can do plenty of things. I think festivals also need creativity. There's always been a way to grab people with many tools. I think we are beginning with these experiences online and I'm sure in one year we could say tremendous creativity came out of this experience.

Gabri: I like the different approaches Yolanda has talked about, and that's also the strength of having so many different visions. I personally don't have a lot of bandwidth for watching a lot online, so I'm still struggling with how long to leave something up. We started experimenting with bringing back one film for the whole month on our website, so people could just watch one of the films. Going back to equity, not everybody can sit down and watch, and not everybody has a computer, especially younger folks. That's a real thing.

Harmony: Thank you so much to this wonderful roundtable on what it means to have a screendance festival in $2020,2021,2022$. There are so many rich ideas to think about further. Let's continue the conversation! 


\section{Biographies}

Harmony Bench is Associate Professor in the Department of Dance at The Ohio State University. Her research addresses practices, performances, and circulations of dance in the contexts of digital and screen media. She is author of Perpetual Motion: Dance, Digital Cultures, and the Common with University of Minnesota Press in 2020, and is at work on a new book on affect and kinesthesia in screendance spectatorship. For several years, Harmony has collaborated with Kate Elswit on bringing the digital humanities and dance history into greater dialogue, most recently with Dunham's Data: Katherine Dunham and Digital Methods for Dance Historical Inquiry (Ref: AH/R012989/1; www.dunhamsdata.org). From 2014-2019, she was co-editor of The International Journal of Screendance with Simon Ellis, and is excited to be guest editing the special issue This Is Where We Dance Now: Covid-19 and the New and Next in Dance Onscreen with Alexandra Harlig.

\section{Email: bench.9@osu.edu}

Website: www.harmonybench.com

Gabri Christa is a dance and filmmaker who hails from Curaçao, Dutch Caribbean and lives in New York. Awards include a Guggenheim for choreography, an ABC television award for Creative Excellence for her short film High School and Pangea Day Festival's One of the World's 100 most promising Filmmakers distinction. Both her films KASITA and One Day at a Time, won best short and best short documentary at the Harlem International Film Festival and can be seen at KweliTV. Her latest short film SON (2021) is currently jury selection at several festivals. As a dancer she worked a.o. with the Bill T. Jones/Arnie Zane Dance company and danced choreographed with Danza Contemporanea de Cuba and DanzAbierta and in her own work. Gabri Christa is an Associate Professor of Professional Practice at Barnard College of Columbia University's Department of Dance and Affiliate Faculty of Film Studies. She teaches Screendance, Composition, Modern Technique, Yoga and a seminar in Dance in Film and directs the Movement Lab at Barnard. She is the founding director of the Moving Body - Moving image Festival a Biennale Screendance Festival around social and social justice issues. She is also a Senior Atlantic Fellow for Equity in Global Brain Health.

Email: gabrichrista@gmail.com

Website: www.gabrichrista.com

Yolanda M. Guadarrama (Mexican) is mainly dedicated to the creation, exhibition and promotion of screendance. Mov en Mov Fest Director, engineer, dancer, choreographer, curator, creator, coeditor of: MOHO Magazine and Editorial; Motion festival, Berlin, 2008. RIFF-Norway curator. REDIV member. 
Email: movenmov@gmail.com

Website: www.yolandamguadarrama.com;

https://movimientoenmovimiento.wordpress.com/;

http://movenmovenglish.wordpress.com

Cara Hagan is an interdisciplinary artist whose work exists at the intersections of movement, digital space, words, contemplative practice, and community. Most recently, Hagan was awarded the inaugural Community Commissioning Residency by the National Center for Choreography for the purpose of creating new screendance work. Her work has also been supported by the Dance Films Association, the Cucalorus Filmed in NC Fund, and The University Research Council at Appalachian State University, where she serves on faculty in the dance studies program. Hagan is the director of ADF's Movies by Movers, an annual, international screendance festival dedicated to the celebration of the conversation between the moving body and the camera. Hagan's scholarly work on screendance has been featured in the International Journal of Screendance, in the anthology, Dance's Duet with the Camera: Motion Pictures, and in her solo-authored book, Celebrating Screendance: Film Festivals and Curatorial Practice, forthcoming from McFarland Publishing.

Email: hagangelbercm@appstate.edu

Website: https://www.carahagan.net/

Kelly Hargraves is a dance film creator and curator from Canada who currently lives in Los Angeles. In September 2018 she was named the Executive and Artistic Director of Dance Camera West, after co-founding the Los Angeles festival of dance film in 2001. Kelly has a Masters in Dance Film from NYU (with a concentration in Dance and Film History), an Honours BFA in Contemporary Dance from Concordia University and an Honours BA in Communication Studies (with a Minor in Theater History) from the University of Windsor. She danced independently in Montréal and New York and was a member of PoMo CoMo (Postmodern Commotion), an artist and scientist collection. Kelly has produced and directed several dance films that are shown internationally, and has been traveling as an invited speaker to dance film festivals since 2009. Hargraves has also been a board member of the Silver Lake Film Festival and the Downtown Los Angeles Film Festival. Through her work with indie film distributors such as First Run Features, Film Movement, and Icarus Film, Kelly has represented artists such as Michael Apted, Lizzie Borden, Cheryl Dunye, Barbara Kopple, Ross McElwee, Monika Truet, Robert Rosenberg and Wayne Wang, amongst many more.

Email: kelly@dancecamerawest.org

Website: https://kellyhargraves.com/

Marisa C. Hayes is a Franco-American artist, scholar and curator working at the crossroads of moving images and the performing arts. Much of her work focuses on explorations of screendance, particularly with regards to its pedagogy and 
curation. She is the founding co-director of the Festival International de Vidéo Danse de Bourgogne in France, an annual platform that is currently preparing its 13th edition. She also curates screendance for the National Choreographic Development Center in Paris and Theatre Freiburg in Germany. She teaches screendance practice, theory and history in higher education internationally, as well as for various public outreach organizations. Her screendance publications include the book The Oxford Handbook of Screendance Studies (ed. Douglas Rosenberg), The International Journal of Screendance, and the book Art in Motion: Current Research in Screendance, which she co-edited for Cambridge Scholars. Her own screendance films have won the Susan Braun Award (New York Dance Films Association) and Pentacle Movement Media's summer video dance prize.

Email: Marisa@videodansebourgogne.com

Website: http://www.videodansebourgogne.com

\section{Resources in order of mention}

Moving Body-Moving Image. Directed, produced, and curated by Gabri Christa. Associate production and co-curation by Abby Lee. https://www.movingbodymovingimage.com

Movimiento en Movimiento. Directed and curated by Yolanda M. Guadarrama. Cocurated by Nayeli Benhumea and Lucitzel Pedrozo. https://movimientoenmovimiento.wordpress.com

R.E.D. International Film Festival (RIFF). Directed and curated by Ella Fiskum. Cocurated by Yolanda M. Guadarrama. http://www.riff-festival.com/

RED Iberoamericana de Videodanza (REDIV). https://rediv.org/

American Dance Festival (ADF)'s Movies by Movers. Directed by Cara Hagan. https://americandancefestival.org/performance/moviesbymovers/

Dance Camera West. Directed by Kelly Hargraves. http://www.dancecamerawest.org/

"2021 DCW Documentary." Uploaded 17 Feb. 2021. YouTube. https://www.youtube.com/watch?v=gqY74IpQvxM

International Video Dance Festival of Burgundy (Festival International de Vidéo Danse de Bourgogne). Directed by Marisa Hayes and Franck Boulègue. www.videodansebourgogne.com 
VidéHomeDance. Centre de Vidéo Danse de Bourgogne. 2020. https://www.numeridanse.tv/videotheque-danse/videhomedance?s 